\title{
Penilaian Aspek Hukum Tata Kelola Hutan Tanaman Rakyat di Kabupaten Barru
}

\author{
Muhammad Fahrum Ahmad1 ${ }^{1,}$, Yusran Yusran², Emban Ibnurusyd Mas'ud ${ }^{2}$ \\ ${ }^{1}$ Tim Layanan Kehutanan Masyarakat; email: fahrum@tlkm.or.id \\ 2Fakultas Kehutanan, Universitas Hasanuddin, Makassar \\ *E-mail: fahrum@tlkm.or.id
}

\begin{abstract}
This study aims to identify the law products in community plantation forest (HTR) management in Barru and to evaluate the law products according to the principles of good governance. This study assessed all of law products related with community plantation forest that were used as guidelines for management implementation in Barru with the principles of good governance. The results showed that there were18 rules guiding the governance of HTR in Barru consisted of 12 rules made by the central government and 6 rules made by local government. The results of this assessment showed that the legal aspects in the governance of HTR in Barru categorised in the medium category (with a value of 1.81). The four aspects analyzed showed the portrait of the law in the governance of HTR (tenure 1,71; forest land use palnning 1,84; forest management 2,34; and forest revenues and economic incentives 1,31).
\end{abstract}

Keywords: barru; law; HTR; governance

DOI: 10.24259/jhm.v9i1.1926

\section{PENDAHULUAN}

Program HTR pada dasarnya bersifat multi-sektor, multi-pihak, dan multi-strata pemerintahan yang memiliki kerangka kelembagaan yang luas dan meliputi berbagai bidang untuk memperkuat pengelolaan hutan sebagai upaya pemerintah dalam menyeimbangkan kebutuhan dan ketersediaan sumberdaya hutan dengan berpedoman pada azas pelestarian. Kompleksitas persoalan di tingkat tapak, persoalan tumpang tindih kebijakan, maupun minimnya kapasitas penyelenggara kehutanan seringkali mendorong lahirnya kebijakan yang bias dan jauh dari prinsip keadilan dan kelestarian. Oleh karena itu, aturan yang dibuat pemerintah pusat semestinya disertai dengan pembuatan peraturan daerah dan aturan lainnya yang menjadi kewenangan pemerintah pada tingkat daerah/kabupaten, sehingga tercipta sinerjitas penyelenggaraan pemerintahan antara pemerintah pusat dan daerah.

Pelaksanaan dan ketersediaan aturan hukum harus berdasarkan landasan fundamental yang menitikberatkan pada prinsip penyelenggaraan yang baik (good governance) yakni prinsip partisipatif, transparan, akuntabel, dan koordinatif. Prinsip-prinsip tersebut merupakan langkah awal dalam menjalankan sebuah kegiatan pengelolaan HTR di suatu daerah.

Kebijakan HTR ini dipandang sebagai salah satu upaya untuk menekan laju deforestasi di Indonesia yang pada tahun 2007 menempatkannya sebagai negara dengan tingkat deforestasi tertinggi di dunia dan negara emitor ketiga setelah USA dan China (World Bank, 2007). Oleh karena itu, ketersediaan aturan hukum akan memberikan jaminan konstitusional yang akan mendukung tata kelola hutan yang sehat. Potret mengenai aspek hukum dalam tata kelola HTR sangat dibutuhkan, baik pada tataran pembuat kebijakan, bagi pelaku usaha, dan bagi masyarakat. Pemerintah membutuhkan gambaran ini sebagai bahan kajian evaluatif yang merujuk pada perbaikan sistem dan perangkat hukum mengenai aturan yang memberikan kejelasan tugas, fungsi, tanggung jawab, dan profesionalitas pemerintah dalam menjalankan kebijakan terkait pemanfaatan pengelolaan, kepemilikan serta penguasaan hutan.

Melalui potret ini, para pengusaha di sektor kehutanan memiliki pertimbangan atas kelayakan investasi serta menganalisis risiko-risiko yang mungkin terjadi di kemudian hari. Di samping itu, kepastian hukum bagi masyarakat juga sangat diperlukan sebagai jaminan dan perlindungan dalam mengelola sumberdaya hutan. 
Berdasarkan permasalahan di atas, penelitian mengenai penilaian aspek hukum sangat dibutuhkan untuk mengetahui apakah produk hukum yang dijadikan pedoman pengelolaan HTR di Kabupaten Barru diselenggarakan secara partisipatif/inklusif, transparan, akuntabel, dan koordinatif. Dengan demikian, alternatif solusi untuk menghadapi berbagai tantangan yang timbul dapat dilakukan secara konstruktif, berkeadilan, dan berkelanjutan guna mendukung penyelenggaraan pembangunan HTR yang diharapkan mampu mewujudkan kemandirian serta peningkatan kesejahteraan bagi masyarakat di Kabupaten Barru.

\section{METODE PENELITIAN}

\subsection{Tempat dan Waktu}

Penelitian ini dilaksanakan pada bulan Juni hingga Juli 2016. Tempat penelitian dilaksanakan di areal Hutan Tanaman Rakyat Kabupaten Barru, Kantor Lembaga Swadaya Masyarakat yang mendampingi HTR Kabupaten Barru, Kantor Dinas Kehutanan Kabupaten Barru, Kantor DPRD Kabupaten Barru dan Kantor Bupati Kabupaten Barru.

\subsection{Kerangka Teori}

Pengaruh hutan hujan tropis di Indonesia memberikan pengaruh besar terhadap emisi gas rumah kaca baik sebagai emitter (penyumbang) maupun sebagai penyerap karbon (FWI, 2014). Pengaruh tersebut memberikan dampak positif apabila tata kelola hutan dilaksanakan dengan efektif dan efisien.

Beragam teori telah memaparkan indikator tata kelola hutan salah satunya World Resource Initiatives (WRI). WRI telah menginisiasi Governance of Forest Initiative menyusun indikator-indikator penilaian tata kelola hutan. Hal ini menjadi basis teori penelitian karena indikator ini berupaya menghimpun berbagai konteks permasalahan terbaru. Indikator penilaian inipun fleksibel termasuk dalam konteks ke-Indonesiaan. Penelitian ini berupaya melakukan integrasi antara indikator penilaian tata kelola hutan hasil inisiasi WRI dengan kebijakan skim Hutan Tanaman Rakyat (HTR). Untuk mendapatkan data spesifik maka fokus penelitian pada penilaian aspek hukum dan dilaksanakan dalam skala Kabupaten.

Penelitian ini dilaksanakan sebanyak tiga tahap secara berurutan dapat dilihat di bawah ini:

1. Tahap desk study dilaksanakan pada tahap awal dengan melakukan penelitian terhadap produkproduk hukum HTR dan review terhadap dokumen penelitian mengenai tata kelola Hutan Tanaman Rakyat.

2. Tahap observasi lapangan dan Indepth Interview dilaksanakan untuk melengkapi dokumen produk hukum di tingkatan kabupaten sekaligus eksplorasi informasi mendalam terhadap seluruh stakeholder dalam hal ini Bupati, sekretaris daerah beserta jajarannya, Biro Hukum Dewan Perwakilan Rakyat Kabupaten Barru Pegawai Dinas Kehutanan Kabupaten Barru, petani hutan pemegang IUPHHKHTR, tokoh masyarakat sekitar kawasan hutan, dan lembaga pendamping lokal

3. Tahap analisis dilaksanakan untuk mendiseminasi data-data yang telah diperoleh melalui Tahap 1 dan Tahap 2. Proses diseminasi dilaksanakan melalui proses analisis menggunakan intrumen penelitian Governance of Forest Initiative (FWI, 2014) yang kemudian dimodifikasi sesuai dengan konteks HTR.

\subsection{Analisis Data}

Instrumen penelitian ini diadopsi dari Governance of Forest Initiative (FWI, 2014). Indikator penilaian aspek hukum dalam penelitian ini merangkum empat prinsip dasar, yakni prinsip transparansi, partisipasi/inklusif, akuntabilitas, dan koordinatif sebagai faktor kunci penilaian. Set indikator ini dimodifikasi untuk menempatkan aspek hukum sebagai fokus kajian dengan mengelompokkan empat tematik pokok yang selanjutnya diilustrasikan melalui Tabel 1 di bawah ini: 
Tabel 1. Indikator Penilaian Aspek Hukum

\begin{tabular}{llll}
\hline & $\begin{array}{c}\text { Tenure } \\
\text { lahan }\end{array}$ & $\begin{array}{l}\text { Perencanaan } \\
\text { Hutan }\end{array}$ & $\begin{array}{l}\text { Manajemen } \\
\text { Sektor } \\
\text { Kehutanan }\end{array}$ \\
\hline Transpaansi & & Hukum & \\
\hline Partisipasi & & & \\
\hline Kkuntabilitas & & & \\
\hline Koordinasi & & & \\
\hline
\end{tabular}

Variabel Governance of Forest Initiative menempatkan variabel hukum, aktor dan praktek sebagai variabel utama penelitian dalam mengukur tata kelola hutan. Pada penelitian ini, untuk mendapatkan data yang spesifik maka fokus penelitian pada aspek hukum yang mengatur tata kelola HTR. Aspek hukum yang dinilai berdasarkan aturan yang mengatur tenurial, perencanaan lahan, manajemen hutan serta sistem dan skema terkait pendapatan sektor kehutanan. Keempat bidang aturan tersebut dinilai berdasarkan kondisi transparansi, partisipasi, akuntabilitas dan kordinasinya.

\subsection{Analisis Data dan Pemberian Nilai}

Analisis data yang digunakan dalam penelitian ini adalah analisis kualitatif dengan model Miles dan Huberman (1984). Menurut Miles dan Huberman aktivitas dalam analisis data kualitatif dilakukan secara interaktif dan berlangsung secara terus menerus sampai tuntas. Aktivitas dalam analisis data, yaitu: (1) data reduction, (2) data display, dan (3) conclusion. Kemudian, proses justifikasi dalam penentuan nilai atau ukuran terhadap aspek hukum akan dilakukan menggunakan analisis kuantitatif.

Analisis kuantitatif digunakan hanya untuk memudahkan justifikasi dan menguatkan narasi atau deskripsi terhadap suatu aspek penilaian. Hasil akhir dari penilaian ini disajikan dalam bentuk indeks yang dihitung menggunakan rumus mean, yaitu menghitung jumlah nilai seluruh unit data kemudian dibagi banyaknya unit data. Indeks penilaian aspek hukum pada HTR di Kabupaten Barru dikategorikan menjadi tiga kelas yaitu tinggi, sedang, dan rendah dengan penjelasan yang dapat dilihat pada Tabel 1 berikut ini

Tabel 2. Kategorisari Indeks Penilaian Aspek Hukum HTR Kabupaten Barru

Nilai Indeks Kategori Uraian

2,34-3,00 Tinggi Nilai rata-rata ideal yang diperoleh dari setiap elemen kualitas, indikator maupun kriteria.

1,67-2,33 Sedang Nilai rata-rata kategori sedang yang diperoleh dari setiap elemen kualitas, indikator maupun kriteria.

$1,00-1,66 \quad$ Rendah Nilai rata-rata yang diperoleh dari setiap elemen kualitas, indikator maupun kriteria

Indeks Tabel 2 diolah dari skor setiap elemen kualitas yang mempunyai gradasi dari nilai tertinggi sampai terendah. Masing-masing bobot ditentukan berdasarkan terpenuhinya instrumen penilaian pada temuan di lapangan. Kategorisasi bobot dapat dilihat pada Tabel 3 di bawah ini: 
Tabel 3. Kategorisasi Bobot Penilaian

\begin{tabular}{lc}
\multicolumn{1}{c}{ Uraian } & Skor \\
\hline Bila data di lapangan memenuhi seluruh unsur dalam elemen kualitas & 3 \\
\hline Bila data lapangan hanya memenuhi sebagian unsur dalam elemen kualitas & 2 \\
\hline Bila data lapangan tidak memenuhi sebagian unsur dalam elemen kualitas & 1 \\
\hline
\end{tabular}

Tahap 1 : Menentukan rata-rata dalam satu indikator dapat dihitung dengan menjumlah nilai/skor hasil penilaian dalam setiap elemen kualitas yang berada dalam satu indikator kemudian dibagi dengan jumlah seluruh elemen kualitas yang terdapat dalam satu indikator dengan menggunakan perbandingan sebagai berikut:

Jumlah skor dari masing-masing elemen kualitas

$\overline{\text { Jumlah seluruh elemen kualitas pada satu indikator }}$

Tahap 2 : Menentukan rata-rata dalam satu kriteria dapat dihitung dengan menghitung jumlah nilai/skor rata-rata hasil penilaian dalam setiap indikator yang berada dalam satu kriteria dibagi dengan jumlah seluruh indikator yang terdapat dalam satu kriteria dengan menggunakan perbandingan sebagai berikut:

Jumlah skor dari masing-masing indikator

Jumlah seluruh elemen kualitas pada satu kriteria

Tahap 3 : Menentukan hasil akhir penilaian dapat dilakukan dengan menghitung jumlah nilai/skor ratarata hasil penilaian dalam setiap kriteria dibagi dengan jumlah seluruh kriteria yang digunakan dalam proses penilaian dengan menggunakan perbandingan sebagai berikut:

Jumlah skor dari masing-masing indikator

Jumlah seluruh kriteria yang digunakan

\section{HASIL DAN PEMBAHASAN}

\subsection{Produk Hukum dalam Tata Kelola HTR di Kabupaten Barru}

Aturan yang digunakan sebagai pedoman oleh pemerintah Kabupaten Barru masih didominasi oleh aturan yang dibuat pemerintah pusat, baik dalam pengaturan birokrasi maupun implementasi kinerja ada tata kelola hutan tanaman rakyat. Grafik persentase aturan yang dipedomani oleh Pemerintah Kabupaten Barru dalam tata kelola hutan tanaman rakyat dapat dilihat pada Gambar 1 di berikut ini: 


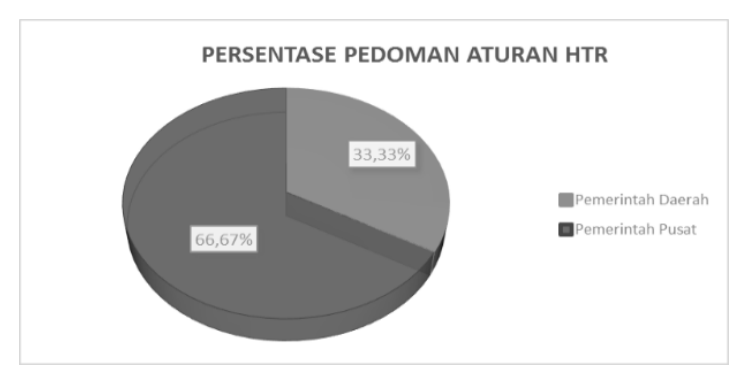

Gambar 1. Grafik Persentase Pedoman Aturan pada HTR di Kab. Barru

Total seluruh aturan yang menjadi pedoman dalam tata kelola HTR di Kabupaten Barru adalah 18 aturan, dimana hanya terdapat 6 aturan yang diterbitkan daerah, sedangkan 12 aturan lainnya diterbitkan oleh pemeirntah pusat.

\subsection{Evaluasi Produk Hukum HTR di Kabupaten Barru}

\section{a. Potret Produk Hukum 4 Aspek Prioritas yang Dianalisis}

Temuan pada penilaian aspek hukum dalam tata kelola Hutan Tanaman Rakyat (HTR) di Kabupaten Barru memberikan informasi dan fakta menarik mengenai potret tata kelola sumberdaya hutan di daerah ini, khususnya pada aspek hukum. Penilaian tersebut didasakan pada empat aspek prioritas yang dianalisis sesuai dengan pedoman pengelolaan hutan yang baik, yakni aspek penguasaan lahan hutan (forest tenure), perencanaan hutan (forest use planning), manajemen hutan (forest management), dan pendapatan kehutanan (forest revenues and economic incentives). Potret empat aspek prioritas yang dianalisis dapat dilihat pada Gambar 2 di bawah ini:

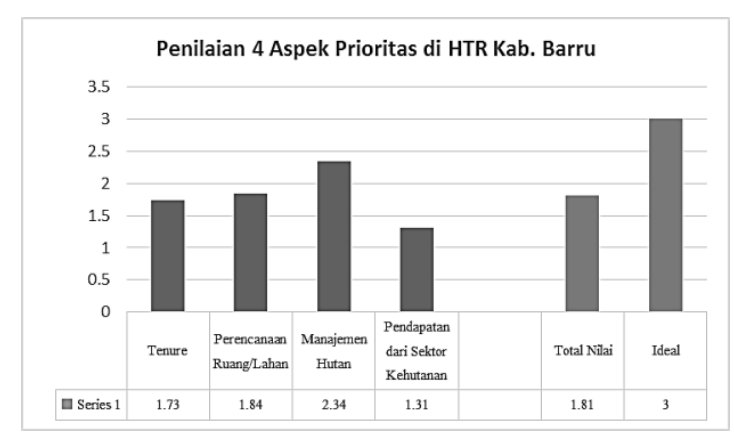

Gambar 2. Grafik Penilaian 4 Aspek Prioritas di HTR Kab. Barru

Hasil penelitian ini menunjukkan bahwa aspek hukum pada pelaksanaan pembangunan HTR di Kabupaten Barru masih ditemukan pelemahan-pelemahan dalam mendorong penerapan prinsip tata kelola yang baik. Hal demikian disimpulkan berdasarkan nilai akumulatif yang diperoleh dari perhitungan sistematis berdasarkan pedoman tata kelola hutan Governance of Forest Inisiative (GFI), dimana hasilnya menunjukkan bahwa aspek hukum pada tata kelola HTR di Kabupaten Barru berada pada kategori sedang dengan nilai 1.81. 


\section{b. Potret Produk Hukum HTR dalam Penerapan Prinsip Tata Kelola yang Baik}

Potret produk hukum HTR Kabupaten Barru dalam prinsip good governance seperti pada Gambar 3 di bawah merupakan hasil penilaian dari keempat aspek prioritas, yaitu tenur, perencanaan ruang/lahan, manajemen hutan, dan pendapaan dari sektor kehutanan yang seluruhnya diakumulasikan dan ditinjau dari prinsip good governance, yakni transparansi, partisipasi, akuntabilitas, dan koordinasi. Penjabaran nilai masing-masing mengenai potret aspek hukum dalam HTR Kabupaten Barru dapat dilihat pada Gambar 3 berikut ini:

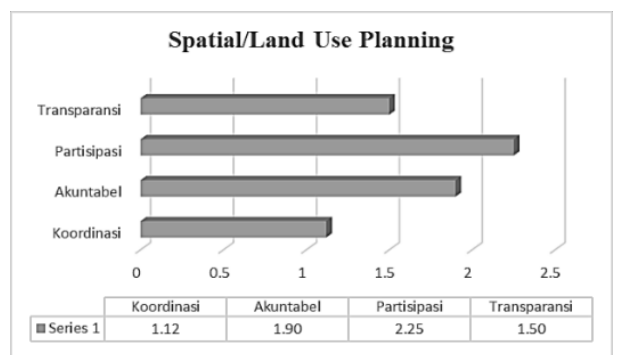

Gambar 3. Grafik Potret Aspek Hukum dalam Tata Kelola HTR Kab.Barru

Hasil penilaian yang ditunjukkan pada Gambar 3 dipengaruhi oleh minimnya aturan yang menjadi landasan pengelolaan hutan tanaman rakyat mulai tahap perencanaan, penataan ruang, pola manajemen, hingga aturan mengenai pendapatan dari sektor kehutanan yang menunjukkan kurangnya porsi atas keterlibatan yang lebih luas kepada publik, khususnya masyarakat terkena dampak dalam tahap penyusunan KLHS, penyusunan RTRW, penatabatasan kawasan hutan dan perubahan peruntukan, pemberian izin usaha, pengusulan dan pemberian izin hutan tanaman rakyat, serta penyusunan perencanaan pengelolaan rehabilitasi hutan lahan (RPRHL).

\section{c. Potret Aspek Hukum Masing-Masing Aspek Prioritas}

\section{Tenure}

Pelaksanaan tata kelola kawasan hutan tanaman rakyat di Kabupaten Barru dijalankan dengan menggunakan instrumen peraturan yang berlaku di tingkat daerah/kabupaten mayoritas berpedoman terhadap aturan pelaksanaan dari pemerintah pusat atau dalam hal ini Kementerian Kehutanan. Kemudian, dalam pengembangan HTR di Kabupaten Barru, masih ditemukan kekurangan pada aturan yang mengharuskan seluruh sektor (di luar kehutanan) melakukan sinkronisasi pengakuan hak, pemanfaatan, pegelolaan, dan pengasaan hutan (tenurial) meskipun dalam Perda nomor 3 tahun 2011 tentang Rencana Pembangunan Jangka Menengah Daerah telah diatur mengenai jaminan pemanfaatan dan pengelolaan yang bersinerji dengan sektor lain atas hak pemanfaatan hasil hutan yang tidak terbatas hanya pada kayu saja. Grafik penilaian pada aspek tenur dapat dilihat pada Gambar 4 berikut ini:

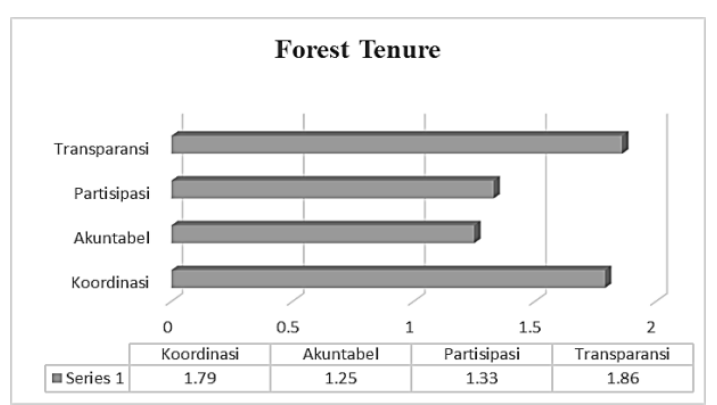

Gambar 4. Grafik Penilaian Aspek Hukum pada Aspek Tenurial di HTR Kab. Barru. 


\section{Perencanaan ruang}

Ketegasan mengenai partisipasi masyarakat dalam penyusunan perencanaan tata ruang telah diatur dalam Undang-undang No. 26 tahun 2007 tentang Penataan Ruang. Sedangkan di lingkup wilayah Kabupaten Barru, telah diterbitkan pada RPJMD melalui Perda Nomor 3 tahun 2011 dan Perda Nomor 4 tahun 2012 yang secara konsisten mendefinisikan pelaksanaan penataan ruang yang sesuai dengan asas berkelanjutan, berwawasan lingkungan yang dilakukan secara demokratis. Transparansi juga menjadi poin penting sebab transparansi dimaknai sebagai upaya Pemerintah Kabupaten dalam menyediakan dan membuka akses informasi pada setiap tahapan pengelolaan sektor hutan dan lahan (Murharjanti, 2013). Namun, berbagai keterbatasan dan persoalan dalam perencanaan tata ruang juga ditemui aspek transparansi, partisipasi, akuntabilitas maupun koordinasi. Grafik penilaian pada aspek perencanaan ruang/lahan dapat dilihat pada Gambar 5 berikut ini:

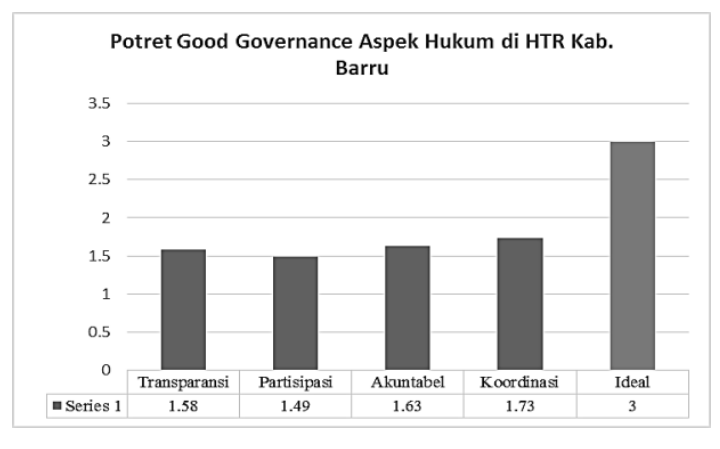

Gambar 5. Grafik Penilaian Aspek Hukum pada Aspek Perencanaan Ruang/Lahan di HTR Kab. Barru.

\section{Manajemen Hutan}

Peraturan perundang-undangan telah menjamin tata kelola hutan yang baik (good forest governance) yang secara umum memuat asas partisipatif, transparantif, akuntabel, dan koordinatif sebagaimana tertuang dalam UU 41 tahun 1999. Dalam kaitannya dengan kejelasan kewenangan dan struktur kelembagaan (termasuk mekanisme kerja) serta partisipasi masyarakat dalam menglola kawasan HTR di tingkat tapak, Peraturan Daerah Nomor 3 tahun 2011 mengenai RPJMD Kabupaten Barru mengimbau agar seluruh elemen, khususnya di tingkat tapak memiliki sistem di dalam lembaga untuk mengedepankan asas transparansi, partisipasi, akuntabilitas, dan koordinasi.

Peraturan Menteri Kehutanan Nomor 31 Tahun 2013 juga memandatkan imbauan yang sama dan menjadi acuan utama pada tata kelola HTR di Kabupaten Barru. Secara definitif, konsistensi mengenai pengelolaan HTR baik di tingkat pusat maupun daerah dilakukan secara harmonis yang ditindak lanjuti melalui Surat Edaran Kementerian Dalam Negeri Nomor 120/253/Sj 16 Januari 2015 kepada seluruh kepala daerah yang menyatakan berdasarkan pasal 404 UU Nomor 23 tahun 2014, serah terima personel, pendanaan, sarana, dan prasarana, serta dokumen Peralatan, Pembiayaan Dan Dokumen (P3D) sebagai pembagian urusan antar pemerintah pusat dan daerah provinsi dan kabupaten di laksanakan paling lambat 2 tahun setelah diberlakukannya UU tersebut. Hal ini juga mendorong agar siklus anggaran terhindar dari stagnasi penyelanggaraan daerah yang berakibat terhentinya pelayanan kepada publik. Grafik penilaian pada aspek manajemen hutan dapat dilihat pada Gambar 6 berikut ini: 


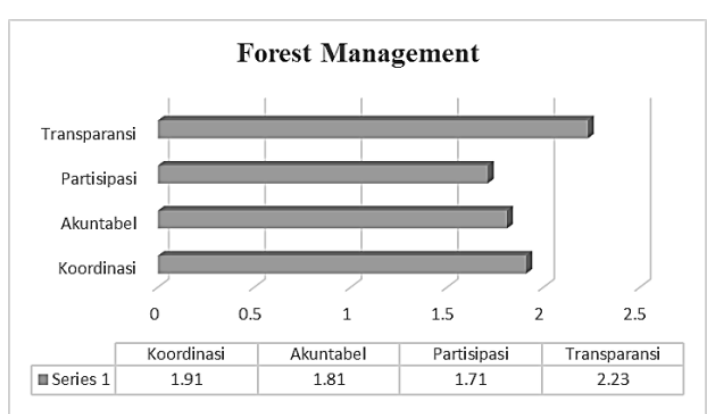

Gambar 6. Grafik Penilaian Aspek Hukum Pada Aspek Manajemen di HTR Kab. Barru

\section{Pendapatan di Sektor Kehutanan}

Progres yang belum signifikan dari pengelolaan HTR di Kabupaten Barru juga menyebabkan belum terbitnya aturan-aturan yang memadai dan mengakomodir seluruh kepentingan seluruh pihak yang berkaitan dengan pendapatan di sektor kehutanan. Walaupun potensi pendapatan melalui pengelolaan HTR terhitung sangat tinggi (Mas'ud, dkk, 2011), namun jaminan aturan belum terlalu kuat.

Peraturan Menteri Kehutanan P.64 tahun 2009 yang dijadikan sebagai acuan pemerintah daerah belum mensyaratkan inisiatif pemerintah untuk melakukan konsultasi publik terhadap rencana penyusunan kebijakan sistem biaya kehutanan. Selain itu, keterlibatan masyarakat dalam pengawasan penerapan sistem biaya kehutanan belum ditentukan dalam aturan tersebut. Meskipun demikian, Pemerintah Kabupaten Barru atau dalam hal ini instansi kehutanan selama ini menggunakan Permendagri Nomor 13 tahun 2006 dalam mengatur sistem keuangan melalui penyusunan Rencana Kerja dan Anggaran (RKA) yang berbasis kompetensi dan kelayakan (feasible).

RPJMD dan SK Nomor 24 tahun 2013 telah mencantumkan pengaturan mengenai adanya insentif ekonomi bagi masyarakat yang tinggal di dalam dan di sekitar hutan, kemudian dalam Juknis Dana Alokasi Khusus (DAK) tahun 2015 terlihat adanya alokasi anggaran yang proporsional di sektor kehutanan. Namun, masih ditemui kekurangan karena aturan tersebut tidak menjelaskan tentang ukuran dan prasyarat sosial dan ekologi dalam pembagian pendapatan kehutanan. Grafik penilaian pada aspek pendapatan dari sektor kehutanan dalam tata kelola hutan tanaman rakyat di Kabupaten Barru terlihat pada Gambar 7:

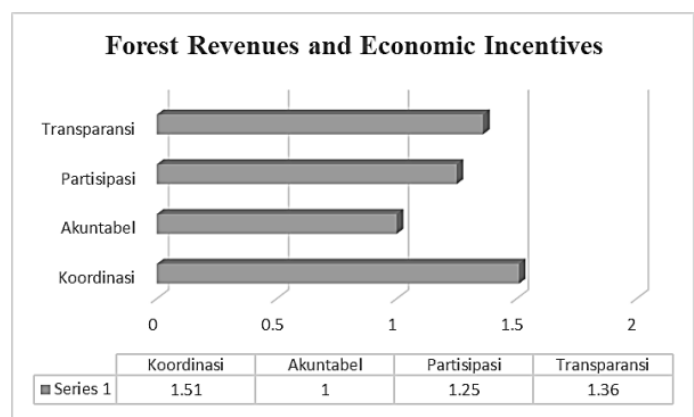

Gambar 7. Grafik Penilaian Aspek Hukum pada Aspek Pendapatan Sektor Kehutanan di HTR Kab. Barru.

\section{KESIMPULAN}

1. Total aturan yang dipedomani Pemerintah Kabupaten Barru dalam pembangunan HTR adalah 18 aturan yang terdiri atas 12 aturan yang diterbitkan pemerintah pusat dan 6 aturan lainnya diterbitkan pemerintah daerah dengan persentase $66.67 \%$ dari pemerintah pusat dan $33.33 \%$ dari peraturan daerah. 
2. Aspek hukum dalam tata kelola hutan tanaman rakyat di Kabupaten Barru berada dalam kategori sedang dengan nilai 1.81 berdasarkan akumulasi nilai dari 4 aspek prioritas yang dianalisis, yakni tenure 1.73; perencanaan ruang/lahan 1.84; manajemen hutan 2.34; dan pendapatan dari sektor kehutanan 1.31. Kemudian, keempat aspek yang dianalisis menunjukkan potret aspek hukum dalam tata kelola HTR dengan nilai masing-masing: transparansi 1.58, partisipasi 1.49 , akuntabilitas 1.63, dan koordinasi 1.73 .

\section{DAFTAR PUSTAKA}

Forest Watch Indonesia (FWI). 2014. Potret Pelaksanaan Tata Kelola Hutan: Studi Kasus Kabupaten Barito Selatan Provinsi Kalimantan Tengah. Bogor: Forest Watch Indonesia.

Mas'ud, Emban Ibnurusyd., Supratman., dan Malamassam, Daud. 2011. Model Pengelolaan Hutan Tanaman Rakyat Pola Mandiri di Desa Bacu-Bacu Kabupaten Barru. Jurnal Hutan dan Masyarakat, Volume 6 No.2, Hal: 93-99.

Miles, Mathew B. Michael Huberman. 1984. Qualitative Data Analysis: A Sourcebook of New Methods. London: Sage Publication, Inc.

Murharjanti, Prayekti. 2013. Indeks Kelola Hutan dan Daerah: Kinerja Pemerintah Daerah Dalam Penglolaan Hutan dan Lahan di Indonesia (Studi Kasus Pada 9 Kabupaten). Jakarta: International Council of Environmental Law (ICEL) Indonesia.

World Bank. 2007. Executive Summary: Indonesia and Climate Change Working Paper on Current Status and Policies. Washington, DC. 